\title{
New Sorbents for Desulfurization of Diesel Fuels via $\pi$-Complexation
}

\author{
Arturo J. Hernández-Maldonado and Ralph T. Yang \\ Dept. of Chemical Engineering, University of Michigan, Ann Arbor, MI 48109 \\ DOI 10.1002/aic.10074 \\ Published online in Wiley InterScience (www.interscience.wiley.com).
}

\begin{abstract}
Desulfurization of a commercial diesel fuel by different adsorbents was studied in a fixed-bed adsorber operated at ambient temperature and pressure. In general, the adsorbents tested for total sulfur adsorption capacity at breakthrough followed the order:

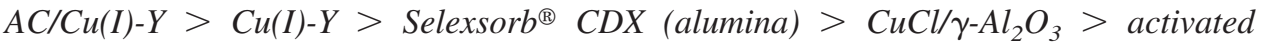
carbon $>C u(I)-Z S M-5$. The best adsorbent, $A C / C u(I)-Y($ layered bed of $15 \mathrm{wt} \%$ activated carbon followed by $\mathrm{Cu}(\mathrm{I}) Y)$, is capable of producing $30 \mathrm{~cm}^{3}$ of diesel fuel per gram of adsorbent with a weighted average content of $0.15 \mathrm{ppmw}-\mathrm{S}$, and about $20 \mathrm{~cm}^{3}$ of diesel fuel per gram of adsorbent with a weighted average content of $0.06 \mathrm{ppmw}-\mathrm{S}$. These low-sulfur fuels are suitable for fuel cell applications. The added layer of carbon not only delayed the sulfur breakthrough significantly but also sharpened the sulfur wavefronts. $G C$-FPD results showed that the $\pi$-complexation sorbents selectively adsorbed highly substituted thiophenes, benzothiophenes, and dibenzothiophenes from diesel, which is not possible with conventional hydrodesulfurization (HDS) reactors. The high sulfur selectivity and high sulfur capacity of $\mathrm{Cu}(\mathrm{I}) Y$ were because of $\pi$-complexation. () 2004 American Institute of Chemical Engineers AIChE J, 50: 791-801, 2004

Keywords: desulfurization of liquid fuels, $\pi$-complexation sorbent, desulfurization by adsorption, desulfurization of diesel, 4-methyl-dibenzothiophene adsorption, 4, 6-dimethyl-dibenzothiophene adsorption
\end{abstract}

\section{Introduction}

The federal government mandates a reduction in gasoline and diesel sulfur levels to 30 and $15 \mathrm{ppm}$, respectively, from the current levels of 300-500 ppmw, to be implemented by 2006 (Krause, 2000). This makes refiners consider eliminating production of onboard transportation fuels because of the high costs that will arise from compliance with such regulations (Parkinson, 2001). For fuel cell applications with gasoline as the feed, the sulfur content should be below 1 ppmw. For automotive fuel cells, liquid hydrocarbons are ideal fuels because of their higher energy density, availability, and safety for transportation and storage. However, the water-gas shift catalysts as well as fuel-cell electrode catalysts are poisoned by sulfur, and the sulfur content in the liquid fuel needs to be preferably less than 0.1 ppmw.

Correspondence concerning this article should be addressed to R. T. Yang at yang@umich.edu.

(C) 2004 American Institute of Chemical Engineers
Hydrodesulfurization (HDS) is very effective in removing thiols and sulfides, but it is not effective for the removal of thiophenic compounds. For example, the $\mathrm{H}_{2} \mathrm{~S}$ produced during reaction of some thiophene derivatives is one of the main inhibitors for deep HDS of unreactive species (Ma et al., 1994; Knudsen et al., 1999). Among the unreacted refractory species are 4-methyl-dibenzothiophene (4-MDBT) and 4,6-dimethyldibenzothiophene (4, 6-DMDBT). These molecules are common in diesel fuels. The methyl groups in these species create a steric effect that hinders the capacity of HDS catalysts to chemisorb the sulfur atoms as depicted in Figure 1a. Such steric hindrance is not present for adsorption by $\pi$-complexation, which is the approach taken in this study. For HDS to meet the new federal government mandates, reactors with volumes 5-15 times larger (depending on the hydrogen pressure) than those currently used are needed. This makes HDS an inappropriate solution and, thus, the use of adsorption to selectively remove the sulfur compounds at ambient conditions an excellent option. Recent studies in our laboratory have already shown that $\pi$-complexation adsorbents are superior to 


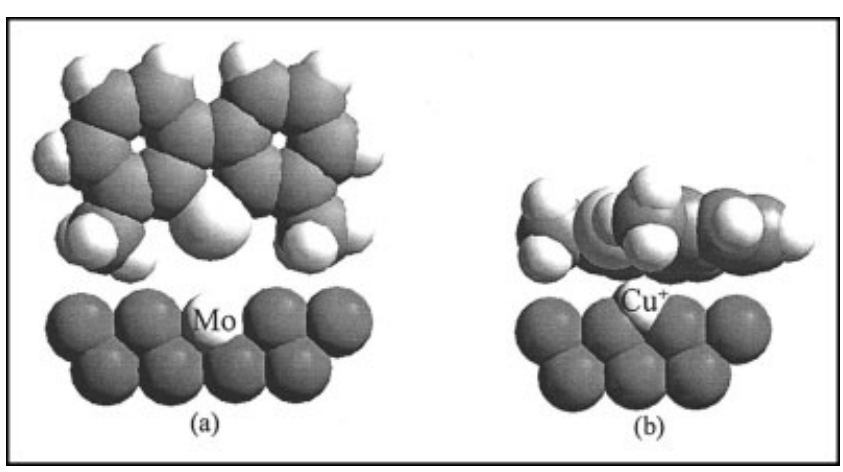

Figure 1. Representation for desulfurization of 4, 6-dimethyl-dibenzothiophene with molybdenum based (a) and copper(l) (b) based adsorbents.

Case (b) corresponds to $\pi$-complexation.

all other adsorbents for this application (Yang et al., 2001, 2002; Takahashi et al., 2002; Hernández-Maldonado and Yang, 2003a,b; Yang et al., 2003).

Molecular orbital calculations have shown that the $\pi$-complexation bonds between $\mathrm{Cu}^{+}$or $\mathrm{Ag}^{+}$and thiophene are stronger than that with benzene (Yang et al., 2001). Thus, $\pi$-complexation sorbents are selective for sulfur removal from transportation fuels (Yang et al., 2001, 2002; Takahashi et al., 2002; Hernández-Maldonado and Yang, 2003a,b). Figure 1b depicts the mechanism involved during $\pi$-complexation between 4, 6-DMDBT and a copper (I) cation. During the complexation mechanism the cation can form the usual $\sigma$ bonds with their s-orbitals and, in addition, their d-orbitals can backdonate electron density to the antibonding $\pi$-orbitals of the sulfur ring of the 4, 6-DMDBT. Methyl groups should not have much effect on $\pi$-complexation, whereas they would enhance adsorption through increased polarizabilities (hence, van der Waals interactions). A detailed discussion of the principles for desulfurization of liquid fuels by adsorption as well as a complete literature review on the subject is available elsewhere (Yang, 2003). Only a partial literature discussion is given later.

Molecular sieves as well as other commercial adsorbents have all been tested for adsorption of sulfur containing compounds and hydrocarbons. Adsorption on these sorbents takes place by means of van der Waals and electrostatic interactions. Wardencki and Staszewski (1974) used 13X zeolites (faujasite) to remove thiophene from $n$-heptane during dynamic or fixedbed adsorption tests at room conditions. The observed sulfur adsorption capacity, however, was greatly affected when the mixture contained a considerable amount of aromatics, such as benzene. Similar tests were also done for other adsorbents, such as 5A zeolite (Kiselev et al., 1962). Ma et al. (2002a,b) studied fixed-bed adsorption of thiophene compounds from jet fuels and diesel with an undisclosed transition metal compound (5 wt. \% loading) supported on silica gel. For jet fuel, they obtained a saturation adsorption capacity of $0.015 \mathrm{~g}$ of sulfur per $\mathrm{cm}^{3}$ of adsorbent, and also showed that breakthrough occurred at about $20 \mathrm{~cm}^{3}$ effluent volume for about $3.2 \mathrm{~cm}^{3}$ of the metal-loaded silica gel. Using a "model diesel" (that is, a synthetic diesel by blending 8 compounds including 2 sulfur compounds), Ma et al. (2002b) obtained a breakthrough capacity of $1 \mathrm{~cm}^{3}$ per gram of adsorbent. The latter was done for the removal of dibenzothiophene and 4, 6-dibenzothiophene mol- ecules only. Collins et al. (1997) also performed fixed-bed adsorption experiments for sulfur removal, but after oxidation of the thiophenic compounds. Oxidation was accomplished with hydrogen peroxide, an acid catalyst and a phase transfer agent. Subsequently, the oxidized sulfur compounds (as sulfones and sulfoxides) were removed from the diesel with silica gel. A breakthrough capacity of about $11 \mathrm{~cm}^{3}$ per gram of silica gel was obtained in this case. Another adsorbent that has been studied was ALCOA Selexsorb, which is an activated alumina. In one specific application (Irvine, 1998), this sorbent was used in a temperature swing adsorption process in order to continuously adsorb hetereoatoms from hydrocarbon mixtures and produced full boiling range FCC gasoline products with an average sulfur content of $30 \mathrm{ppmw}$.

Phillips Petroleum Company developed a process called S Zorb in which the sulfur atoms present in the thiophenic compounds are removed at temperatures in the $340-420^{\circ} \mathrm{C}$ range under a hydrogen atmosphere. They use a proprietary adsorbent, which is believed to be comprised of a bimetallic promotor (Cobalt, Molybdenum, and so on) dispersed on a support formed by zinc oxide and alumina or silica gel (Khare, 2001a,b). For a gasoline feed, they are able to reduce the sulfur content to below $10 \mathrm{ppmw}$. The process for diesel treatment, where the heavy refractory thiophenic compounds are abundant, is under development. Since the aforementioned process needs to remove the sulfur atoms from the aromatic rings, it is believed the same steric effect observed in the conventional HDS processes for elimination of refractory thiophenic compounds (Figure 1a) should play a similar role in the $S$ Zorb process.

In a most recent work, Hu et al. (2003) used a combination of ZSM-5/13X zeolites to extend the life of a reforming catalyst designed for portable power applications. The zeolite combination provided almost an additional 1-h of life to the catalyst at $80 \%$ or better conversion. Although the details about the dynamics involved during the desulfurization step are not detailed, this evidences molecular sieves are promising options for on-board applications, particularly for unexploited options like the $\pi$-complexation adsorbents.

Chemical complexation adsorbents, such as that for $\pi$-complexation, have barely been used in industrial adsorption applications (Yang, 2003). The $\pi$-complexation bonds are stronger than those formed by van der Waals interactions, but they are also weak enough as to be broken by traditional engineering means, such as increasing temperature and/or decreasing pressure (King, 1987). Therefore, this provides opportunities for tailoring and developing new adsorbents for processes where selective adsorption is needed, such as in the case of sulfur removal from fuels. Our group has already developed $\pi$-complexation adsorbents for desulfurization (Yang et al., 2001, 2002; Takahashi et al., 2002; Hernández-Maldonado and Yang, 2003a, 2003b), olefin/paraffin, diene/olefin, and aromatics/aliphatics separations (Yang and Kikkinides, 1995; Rege et al., 1998; Huang et al., 1999a, 1999b; Padin and Yang, 1997, 2000; Padin et al., 1999; Jayaraman et al., 2001; Takahashi et al., 2000, 2001). Hernández-Maldonado and Yang (2003a) found that both copper and silver exchanged faujasite type zeolites, $\mathrm{Ag}-\mathrm{Y}$ and $\mathrm{Cu}(\mathrm{I})-\mathrm{Y}$, are excellent adsorbents for the removal of thiophene molecules from liquid hydrocarbon mixtures. For different zeolites, the breakthrough and saturation adsorption capacities obtained for an influent concentration of $760 \mathrm{ppmw}$ sulfur (or 2000 ppmw thiophene) in $n$-octane followed, respec- 
tively, the order: $\mathrm{Cu}(\mathrm{I})-\mathrm{Y}>\mathrm{Ag}-\mathrm{Y}>\mathrm{H}-\mathrm{Y}>\mathrm{Na}-\mathrm{Y}$, and $\mathrm{Cu}(\mathrm{I})$ $\mathrm{Y}>\mathrm{H}-\mathrm{Y}>\mathrm{Na}-\mathrm{Y}>\mathrm{Ag}-\mathrm{Y}$ (Hernández-Maldonado and Yang, 2003a). In a most recent work Hernández-Maldonado and Yang (2003b) showed that $\mathrm{Cu}(\mathrm{I})-\mathrm{Y}$ together with an activated carbon guard bed layer can desulfurize both commercial gasoline and diesel fuels to a content of less than $0.28 \mathrm{ppmw}$ sulfur. For the case of diesel fuel, the guard bed/Cu(I)-Y combination adsorbed 1.08 and $1.85 \mathrm{wt} \%$ total sulfur at breakthrough point and saturation, respectively. At the breakthrough point, $34.3 \mathrm{~cm}^{3}$ of sulfur-free diesel per gram of combined sorbent was produced.

In this study, we have included known commercial adsorbents and made a direct comparison with the $\mathrm{Cu}(\mathrm{I})-\mathrm{Y}$ zeolites for diesel desulfurization. The commercial adsorbents include activated carbon, $\mathrm{CuCl} / \gamma-\mathrm{Al}_{2} \mathrm{O}_{3}$, and Selexsorb $\mathrm{CDX}$. We also tested a $\mathrm{Cu}(\mathrm{I})-\mathrm{ZSM}-5$ zeolite, which is thought to be appropriate for the removal of small thiophenic compounds. The results were obtained with fixed-bed adsorption/breakthrough techniques together with a GC-FPD (Flame Photometric Detector).

\section{Experimental}

\section{Adsorbent preparation}

The starting adsorbent materials used in this study were Na-Y zeolite $\left(\mathrm{Si} / \mathrm{Al}=2.43\right.$, Strem Chemicals), $\mathrm{NH}_{4}$-ZSM-5 zeolite $(\mathrm{Si} / \mathrm{Al}=10$, ALSI-PENTA Zeolite $\mathrm{GmbH})$, activated alumina $\left(\gamma-\mathrm{Al}_{2} \mathrm{O}_{3}, \mathrm{ALCOA}\right)$, Selexsorb CDX (ALCOA Industrial Chemicals), and type PCB activated carbon (Calgon Corporation).

$\mathrm{Cu}(\mathrm{I})-\mathrm{Y}$ (or reduced $\mathrm{Cu}(\mathrm{II})-\mathrm{Y}$ ) was prepared by first ion exchanging $\mathrm{Na}-\mathrm{Y}$ with a $\mathrm{Cu}\left(\mathrm{NO}_{3}\right)_{2}$ aqueous solution $(0.5 \mathrm{M})$ for $48 \mathrm{~h}$ followed by reduction of $\mathrm{Cu}^{2+}$ to $\mathrm{Cu}^{+}$. The amount of copper in the ion exchange solution was equivalent to a 10 -fold cation exchange capacity. $\mathrm{Cu}(\mathrm{I})-\mathrm{ZSM}-5$ (or reduced $\mathrm{Cu}(\mathrm{II})-$ ZSM-5) was prepared by ion exchanging $\mathrm{NH}_{4}-\mathrm{ZSM}-5$ twice with $\mathrm{Cu}\left(\mathrm{CH}_{3} \mathrm{CO}_{2}\right)_{2}$ aqueous solution $(0.15 \mathrm{M})$ for approximately $24 \mathrm{~h}$. The adsorbents were recovered by filtration and washed with copious amounts of deionized water, followed by drying at $100^{\circ} \mathrm{C}$ for at least $24 \mathrm{~h}$. Activation of both $\mathrm{Cu}(\mathrm{II})-\mathrm{Y}$ and $\mathrm{Cu}(\mathrm{II})-\mathrm{ZSM}-5$ was performed at $450^{\circ} \mathrm{C}$ in pure helium to promote autoreduction of $\mathrm{Cu}^{2+}$ species to $\mathrm{Cu}^{+}$, which is desired for $\pi$-complexation. Autoreduction of cupric ions to cuprous ions in synthetic zeolites has been reported by several groups (Iwamoto et al., 1991; Parrillo et al., 1993; Larsen et al., 1994), and a more detailed discussion on the $\mathrm{Cu}-\mathrm{Y}$ autoreduction process can be found elsewhere (Takahashi et al., 2001, 2002; Hernández-Maldonado and Yang, 2003a).

$\mathrm{CuCl} / \gamma-\mathrm{Al}_{2} \mathrm{O}_{3}$ was prepared with an impregnation process developed by Golden et al. (Golden et al., 1992a,b; Kumar et al., 1994; Golden et al., 1998) in which a dispersing agent is used to achieve a preferred loading of copper. This dispersant serves to stabilize the copper in its +1 state once the material is reduced. Because activated alumina was obtained in pellet form, the adsorbent was crushed into powder form and then activated in air at $350^{\circ} \mathrm{C}$. Afterward, about $10 \mathrm{~g}$ of the alumina was impregnated with a solution containing $\mathrm{CuCl}_{2} \cdot \mathrm{H}_{2} \mathrm{O}$, ammonium citrate $\left(\left(\mathrm{NH}_{4}\right)_{2} \mathrm{C}_{6} \mathrm{H}_{6} \mathrm{O}_{7}\right)$ and deionized water. The amount of solution used was enough to fill the pore volume of the alumina $\left(\sim 0.5 \mathrm{~cm}^{3} / \mathrm{g}\right)$, and to disperse a uniform monolayer of $\mathrm{CuCl}_{2}$. The material was then dried at $170^{\circ} \mathrm{C}$, which is below the decomposition temperature of the citrate. The copper plus one state was obtained by heating the adsorbent with a reducing atmosphere in situ at $90^{\circ} \mathrm{C}$.

Selexsorb CDX is an activated alumina specially formulated by Alcoa Industrial Chemicals for the adsorption of polar organic compounds including sulfur-based molecules (mercaptans, sulfides, disulfides, and thiophenes), nitrogen-based molecules (nitriles, amines, and pyridines), and oxygenated hydrocarbon molecules (alcohols, glycols, aldehydes, ketons, ethers, peroxides). This material was also obtained in pellet form and was crushed into powder form for use during tests.

\section{Reagents and standards}

Diesel samples were obtained from British-Petroleum (BP) gas stations located in Ann Arbor, MI. The diesel was type No. 2 according to BP's specifications. The average total sulfur concentration for the diesel was reported to be 297.2 ppmw. Thiophene, benzothiophenes (BT), and dibenzothiophene (DBT) standards were purchased from Sigma-Aldrich.

\section{Elemental analysis}

$\mathrm{Cu}$ (II)-Y and $\mathrm{Na}-\mathrm{Y}$ adsorbents were characterized with neutron activation analysis (NAA) in the research nuclear reactor of the Phoenix Memorial Laboratory at the University of Michigan. The data was obtained from a 1-min. core-face irradiation delivered via a pneumatic tube to a location with an average thermal flux of $2.13 \times 10^{12}$ neutrons $/ \mathrm{cm}^{2} / \mathrm{s}$. Following irradiation, two separate counts were made, one after a 13-min decay (for $\mathrm{Al}$ and $\mathrm{Cu}$ ), and a second count after a $1 \mathrm{~h}$ and $56 \mathrm{~min}$ decay (for $\mathrm{Na}$ and $\mathrm{K}$ ); both were for $500 \mathrm{~s}$.

The concentrations of $\mathrm{Al}, \mathrm{Na}$, and $\mathrm{K}$ were determined based on comparison with three replicates of the standard reference material NIST1633A (coal fly ash); the determination of $\mathrm{Cu}$ content was evaluated relative to high-purity copper wire. Data reductions for NIST1633A were based on NIST certified values.

\section{Fixed-bed adsorption/breakthrough experiments}

All adsorption/breakthrough experiments were performed in vertical custom made quartz adsorbers equipped with a supporting glass frit. The setup consisted of a low-flow liquid pump equipped with a ceramic piston and cylinder liner, Kynar compression fittings, two Pyrex feed tanks, and a heating element. Initially, the adsorbents were loaded inside the adsorber (between 1 to $2 \mathrm{~g}$ ), and heated in situ at different temperatures. Both $\mathrm{Cu}(\mathrm{II})-\mathrm{Y}$, and $\mathrm{Cu}(\mathrm{II})-\mathrm{ZSM}-5$ adsorbents were autoreduced in flowing helium at $450^{\circ} \mathrm{C} ; \mathrm{CuCl}_{2} / \gamma-\mathrm{Al}_{2} \mathrm{O}_{3}$ was reduced in a carbon monoxide atmosphere at $90^{\circ} \mathrm{C}$; activated carbon (AC), and Selexsorb CDX were activated in helium at 450 and $350^{\circ} \mathrm{C}$, respectively. Temperatures were maintained at steady values with a PID temperature controller. All the gases used for activation were pretreated inline before contacting the sorbent with a 3A-type zeolite. The latter removed trace water from the gases, which would otherwise be adsorbed by the zeolite. After activation treatment, all the adsorbents under study were allowed to cool down to roomtemperature under helium, and then tapped to ensure proper packing. Next, a sulfur-free hydrocarbon was allowed to flow through the sorbent at a rate of $0.5 \mathrm{~cm}^{3} / \mathrm{min}$. After wetting the adsorbent for about $10 \mathrm{~min}$, the feed was switched to commer- 


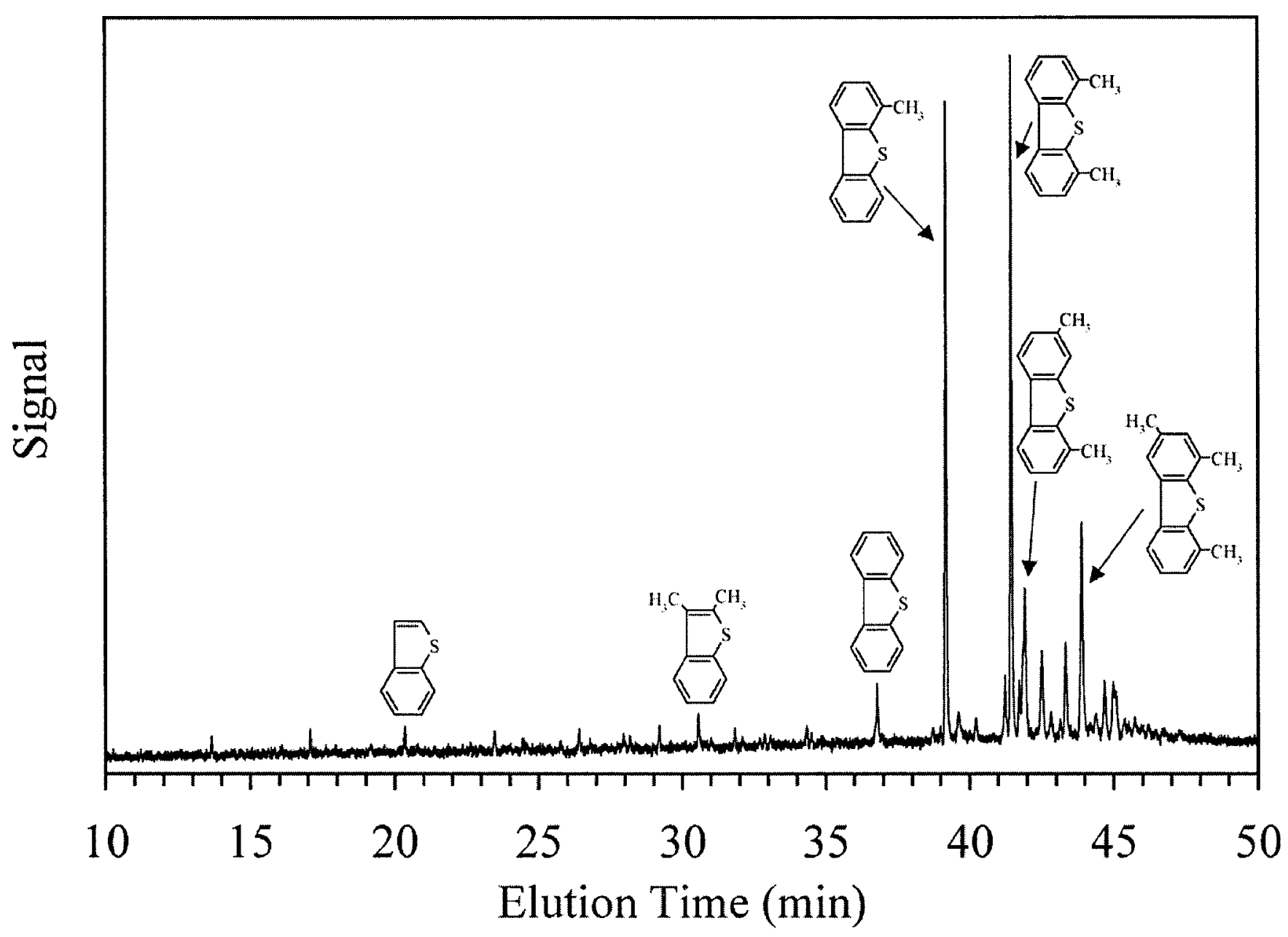

Figure 2. GC-FPD chromatogram of a commercial diesel fuel.

cial diesel at a flow rate of $0.5 \mathrm{~cm}^{3} / \mathrm{min}$. After elution of the hydrocarbon used in the degassing step, effluent samples were collected at regular intervals until saturation was achieved, which depended on the adsorption dynamics and the amount of adsorbent.

\section{Gas chromatography analysis}

All the samples collected during the breakthrough experiments were analyzed with a Shimadzu GC-17A v3 unit equipped with an EC-5 capillary column $(\mathrm{L}=30 \mathrm{~m}$; ID $=0.32$ $\mu \mathrm{m})$ and a flame photometric detector (FPD). The column temperature program was set to increase from $50^{\circ} \mathrm{C}$ to a set value at a $5^{\circ} \mathrm{C} / \mathrm{min}$ rate. For diesel sulfur analysis, the column final temperature was set to $330^{\circ} \mathrm{C}$. In addition, a split mode injection was used for all samples at different ratios. The injection port temperature was also set to $330^{\circ} \mathrm{C}$.

Peak identification information for sulfur compounds present in diesel was gathered after with standards and by retention time comparison with data available in the literature (Ma et al., 1997, 2002a,b; Gates and Topsøe, 1997; Bacaud et al., 2002). For standards, thiophene, BT and DBT solutions were diluted in sulfur-free $n$-octane to a known concentration and then injected for retention time determination. The total sulfur concentration during breakthrough adsorption experiments for die- sel was calculated by integrating the individual peaks in the entire GC chromatogram regions. With the three standards (thiophene, BT and DBT), it was first established that the peaks areas per $S$ were statistically the same for these three molecules. Thus, the total concentration of sulfur compounds was taken to be proportional to the sum of the peaks sulfur concentration values (a similar approach was used by Chawla and Di Sanzo, 1992). This was acceptable for conditions where complete sample elution was achieved after injection and upon correction for noise data. The total elution times for diesel for the GC conditions described earlier was about $60 \mathrm{~min}$. A similar procedure was used to calculate individual sulfur component concentrations during adsorption experiments. Figure 2 shows a GC-FPD chromatogram for as-received diesel fuels. The results are similar to those found in the literature for similar analysis conditions and set-up. It should be mentioned that no quenching effect resulting from hydrocarbons was ever observed during the GC-FPD analysis.

To establish the minimum detection limit of the GC-FPD, solutions of thiophene in $n$-octane, prepared by sequential dilution, were used. Detectable peaks were recorded at concentrations down to 20 ppbw $\mathrm{S}$ (or 50 ppbw thiophene), with a split ratio of 5:1. However, at this condition the GC-FPD signal for as-received diesel fuel gets cutoff because of the high 
Table 1. Composition Data for Cu(II)-Y and Na-Y Zeolites Obtained from Neutron Activation Analysis (NAA)

\begin{tabular}{lcccc}
\hline & \multicolumn{4}{c}{ Molar Ratios } \\
\cline { 2 - 5 } Adsorbent & $\mathrm{Na} / \mathrm{Al}$ & $\mathrm{Cu} / \mathrm{Al}$ & $\mathrm{Si} / \mathrm{Al}$ & Unit Cell Composition \\
\hline $\mathrm{Na}-\mathrm{Y}$ & 0.94 & - & 2.43 & $\mathrm{Na}_{56}\left(\mathrm{Al}_{56} \mathrm{Si}_{136} \mathrm{O}_{384}\right) \cdot 250 \mathrm{H}_{2} \mathrm{O}$ \\
$\mathrm{Cu}(\mathrm{II})-\mathrm{Y}$ & 0.28 & 0.36 & 2.43 & $\mathrm{Cu}_{21} \mathrm{Na}_{14}\left(\mathrm{Al}_{56} \mathrm{Si}_{136} \mathrm{O}_{384}\right) \cdot 250 \mathrm{H}_{2} \mathrm{O}$ \\
\hline
\end{tabular}

content of some refractory dibenzothiophenes. Thus, different split ratios were used for testing diesel fuels for sulfur content at ultra-low concentration ranges.

\section{Nitrogen equilibrium adsorption isotherms}

Some of the adsorbents were tested for surface area and cumulative pore volume measurements. This information was obtained from liquid nitrogen (@-196 ${ }^{\circ} \mathrm{C}$ ) equilibrium isotherms and following standard procedures are found elsewhere. The equilibrium data was gathered with a Micromeritics ASAP 2010 static volumetric analysis unit. Information on this type of analysis and calculations is beyond the scope of this study. More information can be found elsewhere (Horvath and Kawazoe, 1983; Saito and Foley, 1991; Cheng and Yang, 1994).

\section{Results and Discussion}

\section{Adsorbent characterization}

Elemental analyses of some of the adsorbents were achieved by NAA. All the zeolites were in hydrated conditions before testing. As seen in Table 1, ion-exchanging $\mathrm{Na}-\mathrm{Y}$ with $\mathrm{Cu}^{2+}$ resulted in incomplete ion exchange. If it is assumed that one $\mathrm{Cu}^{2+}$ cation compensates for two aluminum tetrahedra, then, for our case the ion exchange resulted in only $72 \%$ substitution of the original sodium ions (that is, $2 \mathrm{Cu} / \mathrm{Al}=0.72$ ). The remaining sodium ions were compensating for the other aluminum tetrahedra; in other words, the $(2 \mathrm{Cu}+\mathrm{Na}) / \mathrm{Al}$ ratio should be unity, which was observed here. This scheme is the simplest one used to describe these zeolites. More elaborated schemes can be found elsewhere (Baes and Mesmer, 1976; Parrillo et al., 1993), including previous work done by our group (Takahashi et al., 2001, 2002; Hernández-Maldonado and Yang, 2003a).

\section{Adsorbent activation, copper autoreduction, and migration}

Because Y zeolite is known to be highly hydrophilic (uptake $>$ 20 wt. \% water at ambient conditions), all the gases used for activation of the adsorbents were pretreated with 3A-Type zeolites before entering the fixed-bed unit. For $\mathrm{Cu}(\mathrm{II})-\mathrm{Y}$ and $\mathrm{Cu}$ (II)$\mathrm{ZSM}-5$, the activation was performed at $450^{\circ} \mathrm{C}$ in helium to promote autoreduction of $\mathrm{Cu}^{2+}$ species to $\mathrm{Cu}^{+}$, which is needed for $\pi$-complexation $(\mathrm{Cu}(\mathrm{I})-\mathrm{Y}$ and $\mathrm{Cu}(\mathrm{I})-\mathrm{ZSM}-5)$.

Mechanisms of autoreduction of $\mathrm{Cu}^{2+}$ in zeolites have been proposed by a number of groups (Iwamoto et al., 1991; Sarkany et al., 1992; Valyon and Hall, 1993). It appears the following mechanism is present during autoreduction of $\mathrm{Cu}(\mathrm{II})$-zeolites

$$
\begin{gathered}
2 \mathrm{CuOH}^{+} \leftrightarrow \mathrm{CuOCu}^{2+}+\mathrm{H}_{2} \mathrm{O} \\
\mathrm{CuOCu}^{2+} \leftrightarrow 2 \mathrm{Cu}^{+}+1 / 2 \mathrm{O}_{2}
\end{gathered}
$$

The $\mathrm{CuOH}^{+}$could be formed during dehydration of the zeolite and/or introduced during ion exchange via hydrolysis mechanisms (Baes and Mesmer, 1976). Valyon and Hall (1993) confirmed the validity of Eq. 1 by analyzing IR data for copper faujasite zeolites also prepared by liquid phase ion exchange. They also identified strong IR bands for extra-framework oxygen (EFO), which is believed to be introduced during the ion exchange. This EFO then counterbalances any aluminum site released during reduction or autoreduction of the copper species.

Larsen et al. (1994) reported that about $40 \%$ of the cupric ions in $\mathrm{Cu}-\mathrm{ZSM}-5$ were reduced under helium at $410^{\circ} \mathrm{C}$. EPR studies done by Takahashi et al. $(2001,2002)$ showed that $50 \%$ of $\mathrm{Cu}^{2+}$ in $\mathrm{Cu}(\mathrm{II})-\mathrm{Y}$ zeolite was reduced under vacuum or helium at $450^{\circ} \mathrm{C}$, which was in good agreement with the findings of Larsen et al. (1994). It should be noted that after several hours of autoreduction, the color of $\mathrm{Cu}(\mathrm{I})-\mathrm{Y}$ was pale green, compared to a bluish green typically observed in $\mathrm{Cu}$ (II)-Y. This was evidence of autoreduction as $\mathrm{Cu}^{+}$should result in a white color (as in $\mathrm{CuCl}$ ). Successful liquid phase thiophene adsorption experiments done by Hernández-Maldonado and Yang (2003a), with $\mathrm{Cu}(\mathrm{I})$-Y zeolites provided further evidence of the reduction of $\mathrm{Cu}^{2+}$.

The adsorption capacity of autoreduced $\mathrm{Cu}-\mathrm{Y}$ observed for simple liquid hydrocarbon mixtures (Hernández-Maldonado and Yang 2003a) has to be due not only to the reduction of the copper ions, but also because of the final, exposed position of the cations after activation and/or during adsorption. $\mathrm{Cu}^{+}$cations must be occupying exposed sites in the $\mathrm{Y}$ zeolite framework, such as sites II and III according to the nomenclature of Smith (1971), in order to interact with the sulfur-containing molecules. Recent studies by Fowkes et al. (2002) have shown that, upon reduction of $\mathrm{Cu}(\mathrm{II})-\mathrm{Y}$, there was a redistribution of cation positions and most of the reduced species $\left(\mathrm{Cu}^{+}\right)$occupied sites I* and II. Lamberti et al. (1997) showed similar results for both reduced $\mathrm{Cu}(\mathrm{II})-\mathrm{Y}$ and $\mathrm{Cu}(\mathrm{I})-\mathrm{Y}$ prepared, respectively, by ion exchange and gas-phase reaction with $\mathrm{CuCl}$ vapor. In addition, some $\mathrm{Cu}^{+}$ions could be induced to migrate to more exposed sites in the presence of guest molecules. Turnes-Palomino et al. (2000) found, based on IR data, that this occurred when $\mathrm{CO}$ molecules were adsorbed on $\mathrm{Cu}(\mathrm{I})-\mathrm{Y}$. Their zeolite was also prepared by vapor-phase exchange of $\mathrm{H}-\mathrm{Y}$ with $\mathrm{CuCl}$. On the basis of their findings, cation migration could also have contributed toward the observed adsorption capacity of this adsorbent.

\section{Fixed-bed adsorption experiments}

After activating the adsorbents in situ, diesel was passed through the fixed-bed and the sulfur concentration in the effluent was monitored as a function of time. Figure 3 shows breakthrough curves obtained during desulfurization of diesel with different adsorbents. The adsorption amounts (normalized per adsorbent weight) were obtained after solving the following equation (Seader and Henley, 1998)

$$
q_{\text {or saturation }}^{\text {breakthrough }}=\left(\frac{\dot{v}}{m_{\text {absorbent }}}\right)\left(\frac{\rho_{\text {fuel }} C_{i}}{M W_{\text {sulfur }}}\right) \int_{0}^{t}\left[1-\frac{C(t)}{C_{i}}\right] d t
$$

The integral part on the righthand side of Eq. 3 is the area above the breakthrough curves. Table 2 summarizes the results obtained for breakthrough and saturation adsorption amounts. 


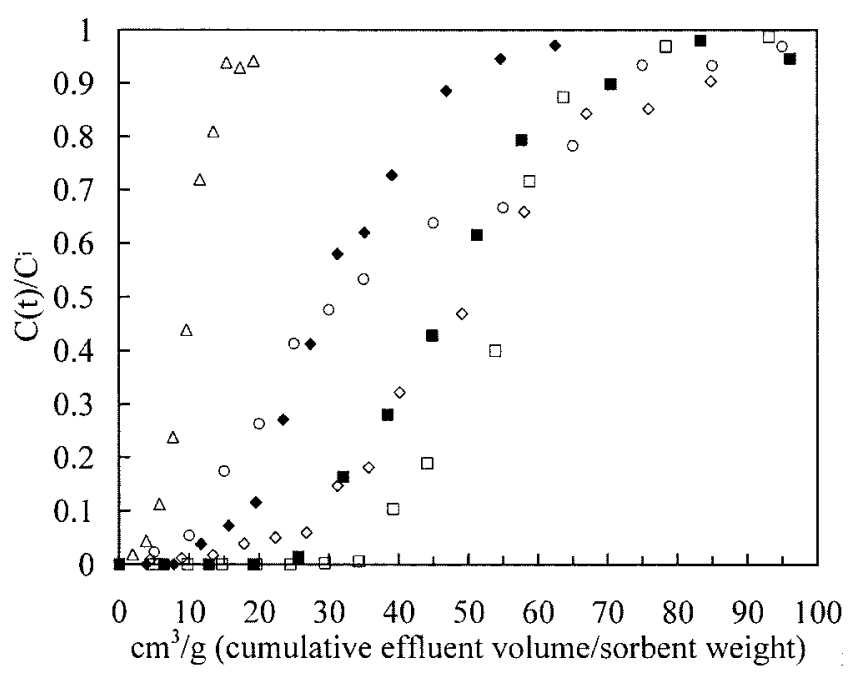

Figure 3. Breakthrough of total sulfur, for diesel feed at room-temperature, in a fixed-bed adsorber with: $\mathrm{Cu}(\mathrm{I})-\mathrm{ZSM}-5(\triangle)$, activated carbon $(O)$, $\mathrm{CuCl} / \gamma-\mathrm{Al}_{2} \mathrm{O}_{3}(\diamond)$, Selexsorb ${ }^{\circledR} \mathrm{CDX}$ alumi$\mathrm{na}(\diamond), \mathrm{Cu}(\mathrm{I})-\mathrm{Y}(\square)$, and $\mathrm{AC} / \mathrm{Cu}(\mathrm{l})-\mathrm{Y}(\square)$.

$C_{i}$ is the total sulfur concentration in the feed, and $\mathrm{C}(\mathrm{t})$ is that in the effluent.

\section{$\mathrm{Cu}(\mathrm{I})-\mathrm{Y}$ Zeolite and activated carbon}

The idea of using a guard bed has been discussed in detail elsewhere (Yang, 1997). In this case, a guard bed (for example, activated carbon) could presorb not only aromatics, but also the largest sulfur-containing compounds, thus extending the capacity of $\mathrm{Cu}(\mathrm{I}) \mathrm{Y}$ for smaller S-compounds (Yang et al. 2002; Hernández-Maldonado and Yang, 2003b). As seen in Figure 3, the activated carbon $(\mathrm{AC})$ and $\mathrm{Cu}(\mathrm{I})$ zeolite combination $(\mathrm{AC} /$ $\mathrm{Cu}(\mathrm{I})-\mathrm{Y})$ is by far the best adsorbent to produce "sulfur-free" diesel fuel. By "sulfur-free" we mean a fuel with a sulfur total content of equal or less than 1 ppmw, unless otherwise noted. This adsorbent was first tested recently by Hernandez-Maldonado and Yang (2003b), during preliminary experiments for both diesel and gasoline desulfurization. The amount of activated carbon in the bed accounts for $15 \mathrm{wt} \%$ of the total bed weight.

To better understand the dynamics and process in the layered bed, it was necessary to study both $\mathrm{Cu}(\mathrm{I})-\mathrm{Y}$ and $\mathrm{AC}$ individually.

Table 2. Breakthrough and Saturation Loadings for Total Sulfur from Diesel on Different Adsorbents

\begin{tabular}{lcccc}
\hline \multicolumn{1}{c}{ Adsorbent } & $\begin{array}{c}\text { Breakthrough } \\
\text { Loading } \\
(\mathrm{mmol} / \mathrm{g})\end{array}$ & $\begin{array}{c}\text { Saturation } \\
\text { Loading } \\
(\mathrm{mmol} / \mathrm{g})\end{array}$ & $\begin{array}{c}\text { Copper } \\
\text { Loading } \\
(\mathrm{mmol} / \\
\mathrm{g})\end{array}$ & $\begin{array}{c}\text { Sulfur-to- } \\
\mathrm{Cu}^{+} \text {Molar } \\
\text { Ratio at } \\
\text { Breakthrough }\end{array}$ \\
\hline $\mathrm{Cu}(\mathrm{I})-\mathrm{Y}$ & 0.17 & 0.38 & 1.50 & $0.23^{* *}$ \\
$\mathrm{AC} / \mathrm{Cu}(\mathrm{I})-\mathrm{Y}^{*}$ & 0.24 & 0.42 & 1.50 & - \\
$\mathrm{Selexsorb} \mathrm{CDX}$ & 0.08 & 0.37 & - & - \\
$\mathrm{AC}(\mathrm{PCB})$ & 0.02 & 0.30 & - & - \\
$\mathrm{CuCl} / \gamma-\mathrm{Al}{ }_{2} \mathrm{O}_{3}$ & 0.08 & 0.24 & $2.93 \dagger$ & 0.03 \\
$\mathrm{Cu}(\mathrm{I})-\mathrm{ZSM}-5$ & 0.01 & 0.08 & $\ddagger$ & - \\
\hline
\end{tabular}

*Adsorbent bed contained two layers: the first layer was PCB activated carbon (AC) followed by $\mathrm{Cu}(\mathrm{I})-\mathrm{Y}$ zeolite. AC accounts for $15 \mathrm{wt} \%$ of the bed weight.

**After auto-reduction of $50 \%$ of copper (II) cations.

$†$ Calculated assuming a monolayer of $\mathrm{CuCl}_{2}$ is formed after impregnation of the alumina. A hexagonal closed-pack model was assumed.

\$Not analyzed because of the low adsorption capacity.

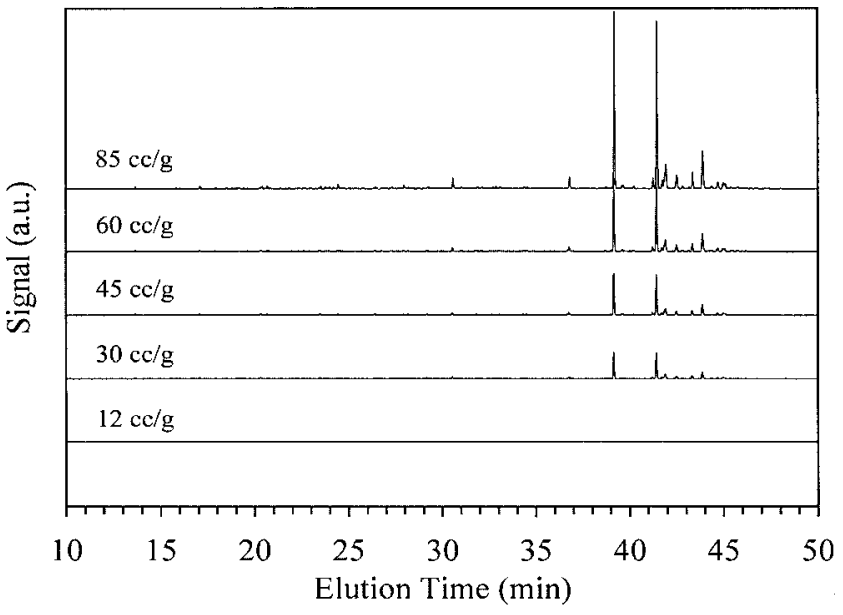

Figure 4. Progression of GC-FPD chromatograms of sulfur compounds in the effluent during diesel treatment with $\mathrm{Cu}(\mathrm{I})-\mathrm{Y}$.

Also shown is the effluent volume normalized by the total weight of adsorbent.

As seen in Figure 3, $\mathrm{Cu}(\mathrm{I})-\mathrm{Y}$ alone is capable of processing 22.4 $\mathrm{cm}^{3}$ of "sulfur-free" diesel per grams of adsorbent. The total sulfur content during treatment with $\mathrm{AC}$, however, breaks through almost immediately (see open circles in Figure 3). This is expected because activated carbon adsorbs both aromatic and thiophenic compounds by van der Waals and electrostatic interactions. Thus, larger molecules (with higher polarizabilities) were preferentially adsorbed by carbon, with no selectivity for thiophenic molecules. A detailed discussion about this can be found elsewhere (Choma et al., 1993; Takahashi and Yang, 2002; Hernandez-Maldonado and Yang, 2003b).

GC-FPD data was also useful to follow the evolution of selected individual compounds present in commercial diesel fuels (see Figure 2 for reference). An example, of GC-FPD evolution chromatograms for diesel treatment with $\mathrm{Cu}(\mathrm{I})-\mathrm{Y}$ is presented in Figure 4. Among the many thiophenic molecules present in diesel fuel, only four were selected for the selectivity studies: benzothiophene (BT), dibenzothiophene (DBT), 4-MDBT, and 4, 6-DMDBT. The last two molecules are the most difficult to remove in desulfurization treatment processes for transportation fuels. As mentioned earlier, both 4-MDBT, and 4, 6-DMDBT remain unreacted in HDS. The concentration of these two molecules is the highest among the sulfur compounds present in commercial diesel (Figure 2).

The detailed breakthrough curves of the four major thiophenic compounds are shown in Figures 5, 6, and 7, for, respectively, $\mathrm{Cu}(\mathrm{I}) \mathrm{Y}$, activated carbon, and layered bed of $\mathrm{AC} / \mathrm{Cu}(\mathrm{I}) \mathrm{Y}$. As mentioned, aromatic compounds are the main competing adsorbates for the thiophenic compounds (see Table 3 for typical diesel aromatic composition). For the diesel being studied, Hernández-Maldonado and Yang (2003b) estimated an aromatic content of about 24.7 wt. \% from FTIR analysis.

The breakthrough behaviors for the $\mathrm{Cu}(\mathrm{I}) \mathrm{Y}$ and activated carbon beds were expected. For activated carbon (Figure 6), breakthrough of all four thiophenic compounds occurred instantly because there was no selectivity for these compounds over nonthiophenic aromatic compounds. The order of breakthrough followed that of molecular weights (or polarizabili- 


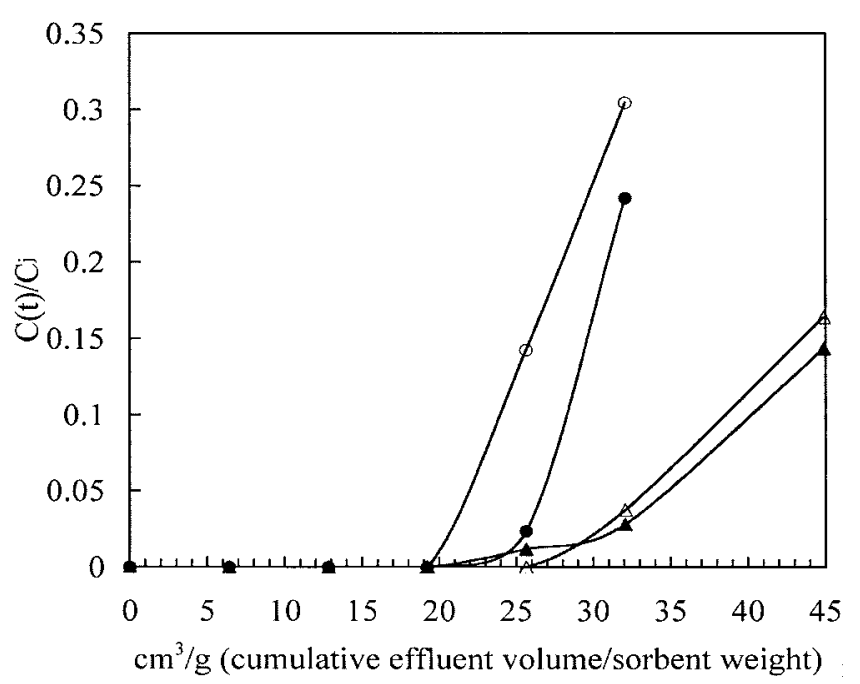

Figure 5. Breakthrough curves of benzothiophene $(O)$, dibenzothiophene ( $(0)$, 4-methyl-dibenzothiophene $(\Delta)$ and 4, 6-dimethyl-dibenzothiophene $(\Delta)$ in a fixed-bed adsorber of $\mathrm{Cu}(\mathrm{l})-\mathrm{Y}$ adsorbent, for diesel feed at room-temperature.

ties); the smaller molecules broke through earlier. For $\mathrm{Cu}(\mathrm{I}) \mathrm{Y}$ (Figure 5), the long delay of the breakthrough of these thiophenic compounds was a direct result of $\pi$-complexation. The order of breakthrough also followed that of molecular weights. Moreover, the dispersive wavefronts of the two largest molecules (4-MDBT and 4, 6-DMDBT) (compared to that of the two smaller molecules) indicated some degree of diffusion limitation in zeolite (Figure 5).

Comparing the breakthrough behaviors of $\mathrm{Cu}(\mathrm{I}) \mathrm{Y}$ and the layered bed of $\mathrm{AC} / \mathrm{Cu}(\mathrm{I}) \mathrm{Y}$ (Figures 5 and 7), two conclusions emerge: (1) breakthroughs of all 4 molecules were delayed by the added layer of activated carbon, and (2) the wavefronts of all 4

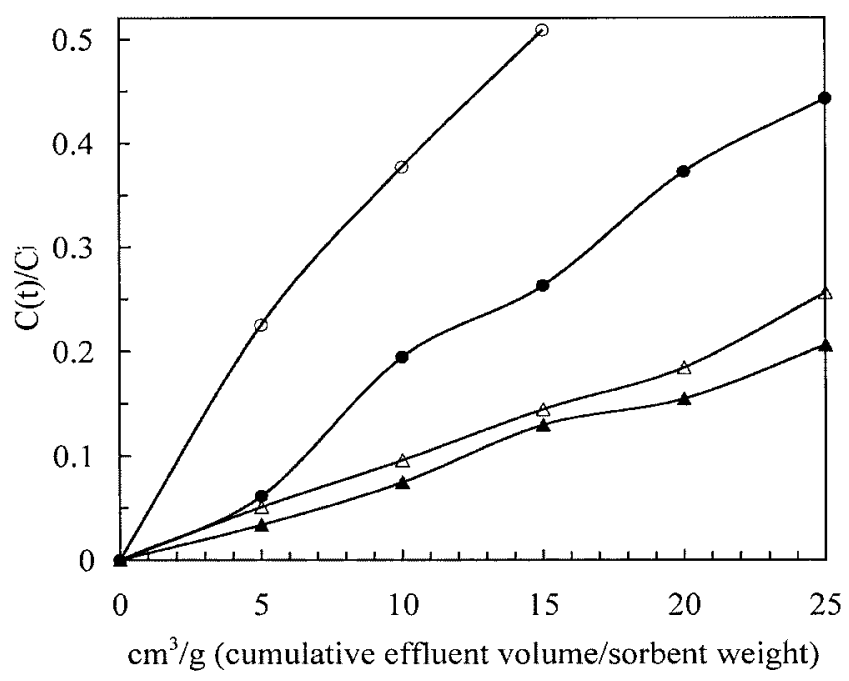

Figure 6. Breakthroughs of benzothiophene $(\bigcirc)$, dibenzothiophene (O), 4-methyl-dibenzothiophene $(\triangle)$, and 4,6-dimethyl-dibenzothiophene $(\Delta)$ in a fixed-bed adsorber of activated carbon adsorbent, for diesel feed at room-temperature.

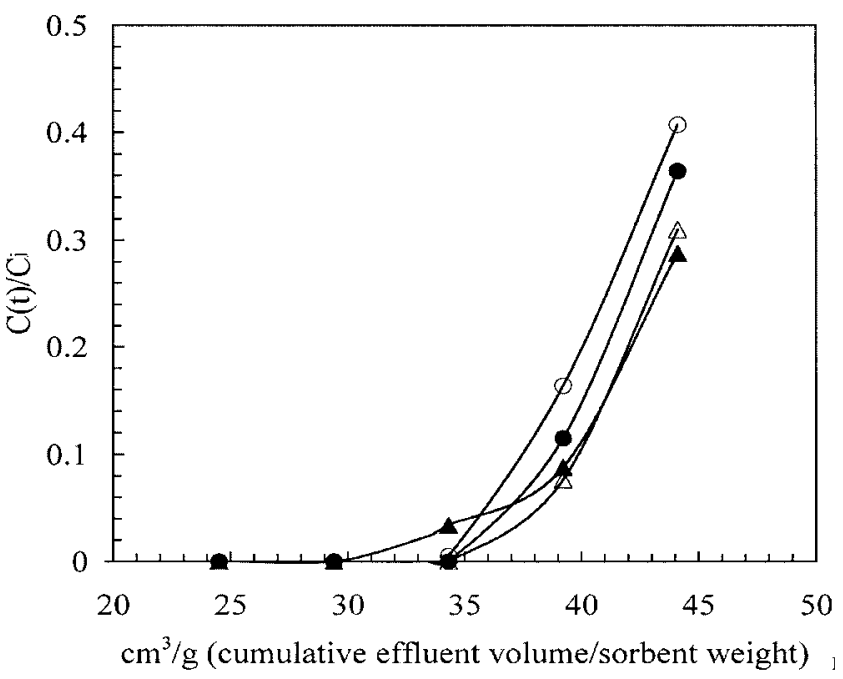

Figure 7. Breakthroughs of benzothiophene $(\bigcirc)$, dibenzothiophene (O), 4-methyl-dibenzothiophene $(\triangle)$, and 4, 6-dimethyl-dibenzothiophene $(\Delta)$ in a fixed-bed adsorber with $\mathrm{AC} / \mathrm{Cu}(\mathrm{l})-\mathrm{Y}$ adsorbent, with diesel feed at room temperature.

compounds (especially the 2 largest molecules) were sharpened by the added activated carbon. The wavefronts of all 4 compounds in these two beds are illustrated in Figure 8. These wavefronts were constructed directly from the breakthrough data, and were given for the same time before breakthrough.

The sulfur analysis (Figure 2) showed that there existed a number of thiophenic compounds that were larger than 4, 6-DMDBT. There also existed a significant number of larger aromatic, nonthiophenic compounds. In fact, the commercial diesel typically contains over 150 different compounds. The results shown in Figure 8 indicate that the added layer of carbon had high selectivities for these large molecules, and, hence, prevented them from entering the $\mathrm{Cu}(\mathrm{I}) \mathrm{Y}$ bed. Without the guard bed, these largest molecules would have entered the main bed and subsequently occupied the adsorption sites as well as partially blocking the pores of the zeolite. Thus, the guard bed not only delayed the breakthrough of the sulfur compounds, but also sharpened their wavefronts by eliminating pore blockage.

\section{$\mathrm{CuCl} / \mathrm{\gamma}-\mathrm{Al}_{2} \mathrm{O}_{3}$}

This adsorbent has been used commercially for CO separation and recovery by pressure swing adsorption (Golden et al., 1992a,b, 1998; Kumar et al., 1993). The adsorbent removes the CO from methane by means of $\pi$-complexation. Figure 3 shows the adsorbent is capable of processing about $10 \mathrm{~cm}^{3}$ of "sulfur free" diesel per grams of solid. Initially, this adsorbent matrix was expected to perform better because of the high loadings of cuprous ions. For $\mathrm{Cu}(\mathrm{I})-\mathrm{Y}$, Takahashi et al. (2001) used electron paramagnetic resonance (EPR) studies to show that about $50 \%$ of the $\mathrm{Cu}^{2+}$ cations are autoreduced to $\mathrm{Cu}^{+}$, whereas for $\mathrm{CuCl} / \gamma-\mathrm{Al}_{2} \mathrm{O}_{3}$ Golden et al. (1998) found $80-85 \%$ of the $\mathrm{Cu}^{2+}$ is reduced. These results were used here to obtain the ratios of sulfur molecules adsorbed per $\mathrm{Cu}^{+}$on $\mathrm{Cu}(\mathrm{I})-\mathrm{Y}$ and $\mathrm{CuCl} / \gamma-\mathrm{Al}_{2} \mathrm{O}_{3}$ (see Table 2). This is clear evidence that most of the copper ions in $\mathrm{CuCl} / \gamma-\mathrm{Al}_{2} \mathrm{O}_{3}$ were not available for $\pi$-complexation with the thiophenic molecules. Because ammonium 
Table 3. Typical Aromatic Composition of Commercial Diesel Fuels

\begin{tabular}{cccccc}
\hline & \multicolumn{5}{c}{ Typical Composition (vol\%) } \\
\cline { 2 - 5 } Total Aromatics & Benzene & Toluene & Xylene & Ethylbenzene & Cumene \\
\hline $15.7-47.2$ & $0-0.02$ & $0-0.18$ & $0.04-0.71$ & $0.02-0.7$ & $0.01-0.06$ \\
$(31.8)$ & $(0.01)$ & $(0.05)$ & $(0.15)$ & $(0.04)$ & $(0.02)$ \\
\hline
\end{tabular}

Note: Data available from British Petroleum (BP), 2001 TRW Summer Motor Gasoline Survey Report, and AAM Diesel Fuel Surveys.

*Average values are shown in parentheses.

citrate is used to help disperse the copper cations during the impregnation process and stabilize them after reduction, it cannot be eliminated during any of the steps involved in the adsorbent activation (see Experiment section). This species should decrease the adsorption capacity considerably. Figure 9 shows liquid nitrogen adsorption isotherms for $\gamma-\mathrm{Al}_{2} \mathrm{O}_{3}$ and $\mathrm{CuCl} / \gamma-\mathrm{Al}_{2} \mathrm{O}_{3}$ obtained after activation under vacuum at a temperature equal to that of the process described in the original recipe for $\mathrm{CO}$ adsorption (that is, $170^{\circ} \mathrm{C}$ ). It is clear that the capacity is decreased both in the low and high-pressure regions. BET surface areas obtained from the isotherms were 338 and $175 \mathrm{~m}^{2} / \mathrm{g}$ for $\gamma-\mathrm{Al}_{2} \mathrm{O}_{3}$ and $\mathrm{CuCl} / \gamma-\mathrm{Al}_{2} \mathrm{O}_{3}$, respectively. The corresponding cumulative pore volumes were 0.20 and 0.11 $\mathrm{cm}^{3} / \mathrm{g}$, which represents a $45 \%$ percent reduction. This indicates a degree of pore clogging which should come only from the dispersing agent. For individual sulfur component adsorption, $\mathrm{CuCl} / \gamma-\mathrm{Al}_{2} \mathrm{O}_{3}$ adsorbent also prefers refractory compounds (see Figure 10), which indicates $\pi$-complexation with those compounds.

\section{Selexsorb CDX alumina}

Alcoa Industrial Chemicals Selexsorb CDX adsorbent is a modified activated alumina designed to remove sulfur-based molecules, such as mercaptans, sulfides, disulfides, and thiophenes among many others. Irvine (1998) developed a commercial process that uses Selexsorb to reduce the sulfur content of fuels to about 30 ppmw sulfur or less. Figure 3 shows the breakthrough curve for diesel total sulfur content after treatment with Selexsorb CDX (open diamonds). Although the sulfur content breaks through after a short time, the Selexsorb

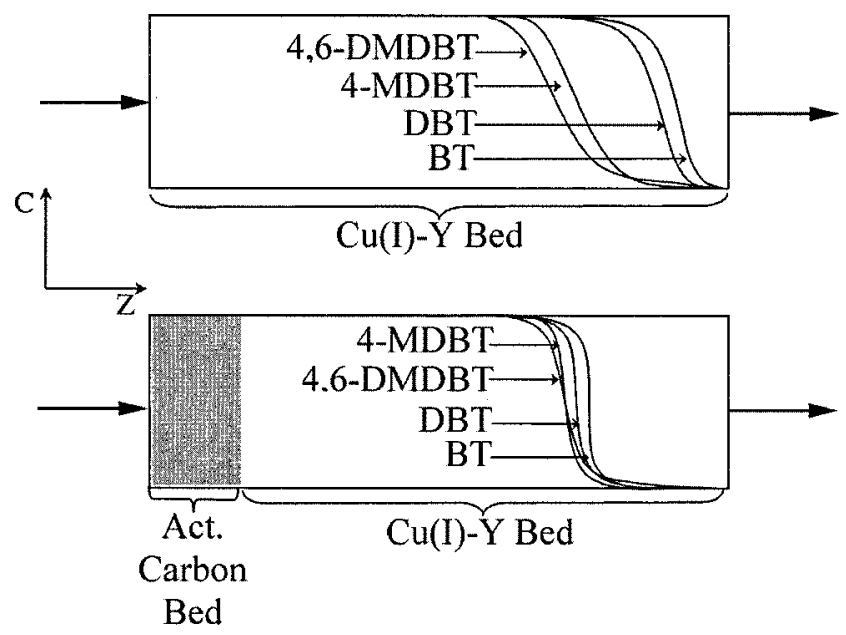

Figure 8. Concentration wavefronts of 4 sulfur compounds in adsorbers of $\mathrm{Cu}(\mathrm{I}) \mathrm{Y}$ and $\mathrm{Cu}(\mathrm{l}) \mathrm{Y}$ layered with $15 \%$ activated carbon, with diesel feed. is capable of treating about $27 \mathrm{~cm}^{3}$ of fuel per gram of adsorbent with a content of 25.4 ppmw S or less. This compares very well to the results claimed by Irvine in his patent. Figure 11 shows individual component adsorption breakthrough curves also obtained for GC-FPD data. The early breakthrough behavior is clearly shown.

\section{$\mathrm{Cu}(\mathrm{I})-\mathrm{ZSM}-5$}

Weitkamp et al. (1991) and King et al. (2000) studied ZSM-5 for removing thiophene from different solutions with fixed-bed breakthrough experiments. Weitkamp et al. (1991) did both vapor and liquid phase removal of thiophene from benzene, but at concentrations an order of magnitude higher than that present in gasoline and diesel. In general, they obtained sulfur removal capacities of about $1.4 \mathrm{wt} . \%$ at saturation for a 0.5 wt. \% thiophene concentration. King et al. (2000) also performed vapor phase fixed-bed breakthrough experiments to remove thiophene $(1 \mathrm{wt}$ \%), but from toluene and p-xylene instead of benzene. Although selectivity toward thiophene was accomplished, saturation adsorption capacities were low $(\sim 1$ wt. \%). In addition, the small pore dimensions of ZSM-5 (0.52 $-0.56 \mathrm{~nm}$ ) would limit the passage of sulfur compounds with more than one ring (that is, benzothiophenes and dibenzothiophenes), which are also present in diesel. However, it was desired to test a copper exchanged version of this zeolite in order to understand the capabilities.

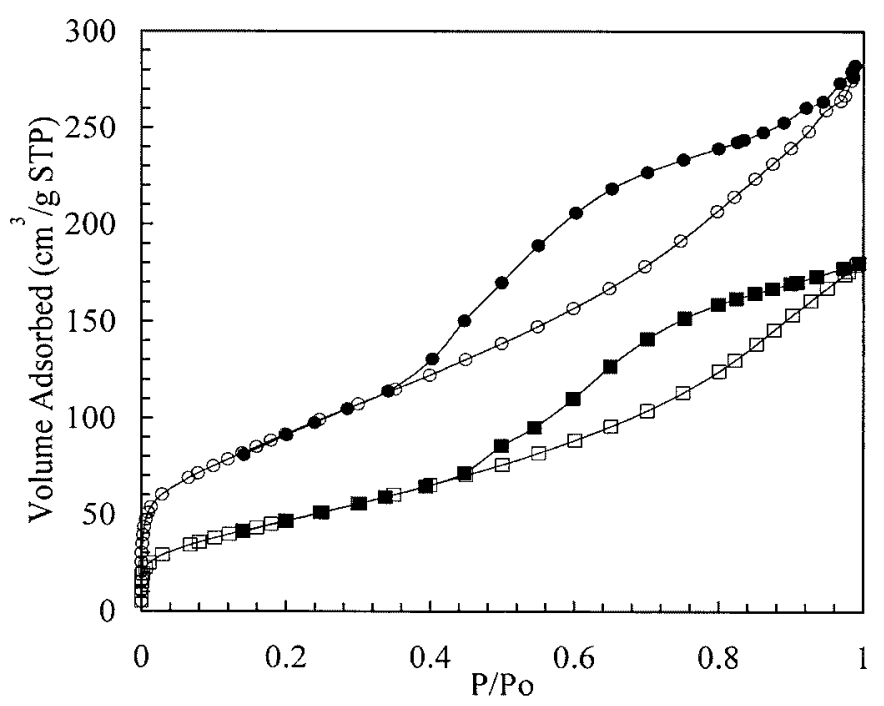

Figure 9. Equilibrium adsorption/desorption isotherms for nitrogen at $-196^{\circ} \mathrm{C}$ on $\gamma-\mathrm{Al}_{2} \mathrm{O}_{3}(O)$ and $\mathrm{CuCl}_{2} / \gamma-\mathrm{Al}_{2} \mathrm{O}_{3}(\square)$.

Open and closed symbols represent adsorption and desorption, respectively. 


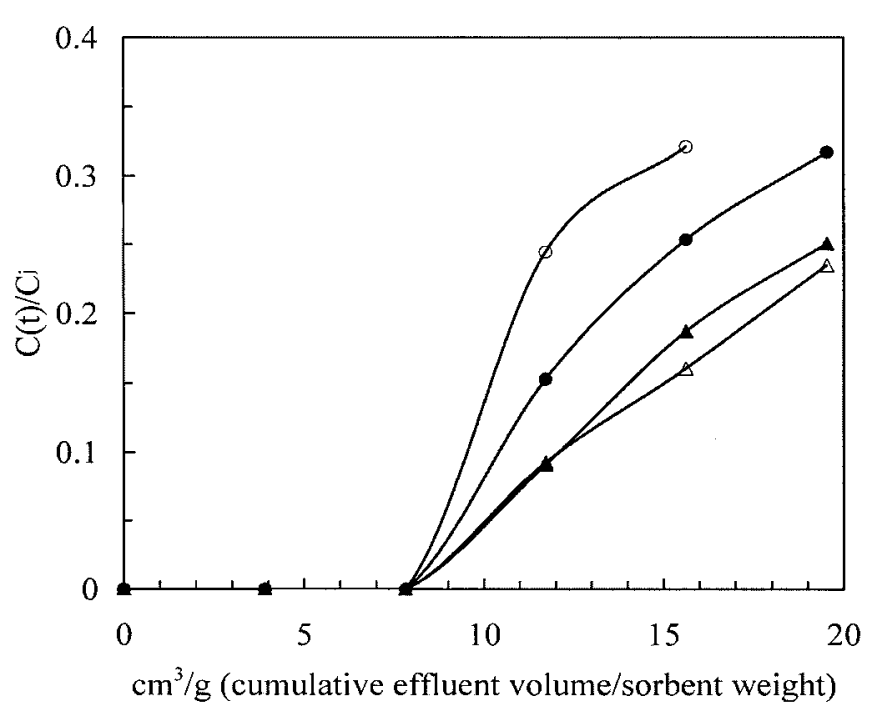

Figure 10. Breakthrough of benzothiophene $(O)$ or dibenzothiophene (O) or 4-methyl-dibenzothiophene $(\triangle)$, or 4 , 6-dimethyl-dibenzothiophene $(\Delta)$ in a fixed-bed adsorber with $\mathrm{CuCl} / \gamma-\mathrm{Al}_{2} \mathrm{O}_{3}$ adsorbent, with diesel feed at room-temperature.

Figure 3 shows $\mathrm{Cu}(\mathrm{I})$-ZSM-5 offers little capacity for adsorption of total sulfur from diesel fuels. Individual component breakthrough curves, however, show that this adsorbent is capable of adsorbing nonsubstituted BT and DBT molecules (see Figure 12). Because the refractory compounds have methyl groups located in critical positions (as shown in Figure 2 ), it will be difficult for these molecules to enter the small channel system of ZSM-5. Thus, ZSM-5 is not suitable for desulfurization of diesel fuels in which refractory compounds are more than abundant, at least without the use of a guard bed.

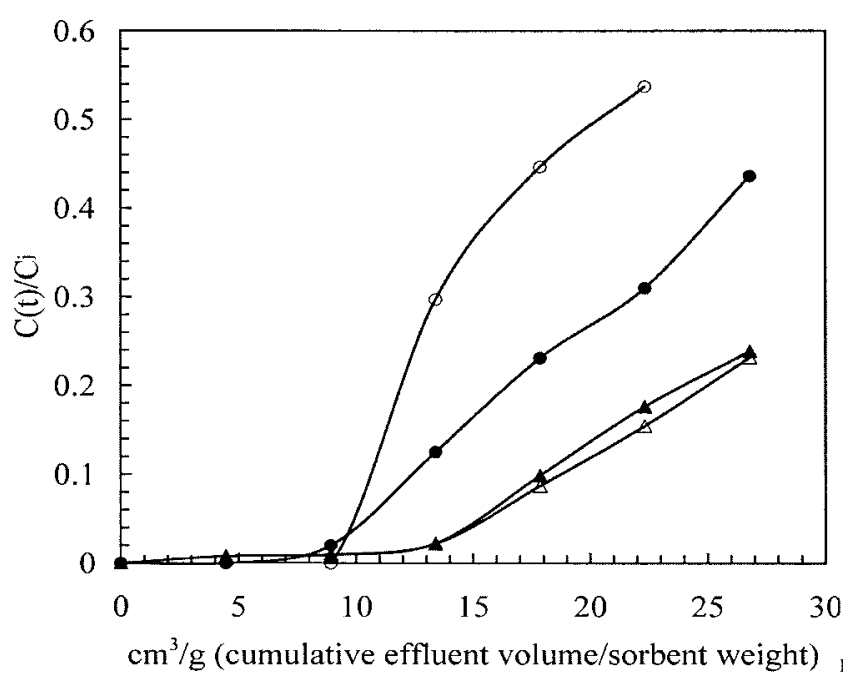

Figure 11. Breakthrough of benzothiophene $(\bigcirc)$ or dibenzothiophene (O) or 4-methyl-dibenzothiophene $(\triangle)$, or 4, 6-dimethyl-dibenzothiophene $(\Delta)$ in a fixed-bed adsorber with Selexsorb CDX alumina, with diesel feed at room- temperature.

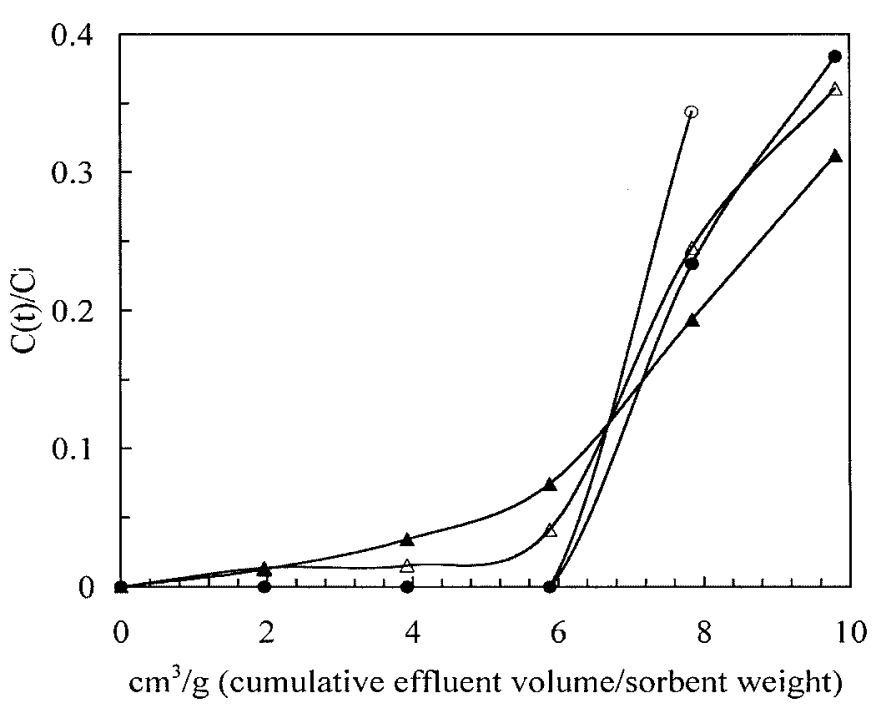

Figure 12. Breakthrough of benzothiophene $(O)$ or dibenzothiophene (O) or 4-methyl-dibenzothiophene $(\triangle)$, or 4, 6-dimethyl-dibenzothiophene $(\Delta)$ in a fixed-bed adsorber with $\mathrm{Cu}(\mathrm{l})-\mathrm{ZSM}-5$ adsorbent, with diesel feed at room- temperature.

\section{Diesel minimum sulfur content after treatment}

To determine the actual minimum sulfur content of the treated diesel fuels, it was necessary to carefully adjust and optimize the GC-FPD detection limits and then focus on the initial regions of the breakthrough curves. Figure 13 shows diesel total sulfur concentration data up to the breakthrough point after treatment with $\mathrm{AC} / \mathrm{Cu}(\mathrm{I})-\mathrm{Y}$, which is the best adsorbent studied here. Note the scale on the $y$-axis is in the ultra-low concentration region. On average, the adsorbent can produce $30 \mathrm{~cm}^{3} / \mathrm{g}$ of diesel fuel with a total sulfur content of 0.15 ppmw or 150 ppbw. For fuel cell applications where

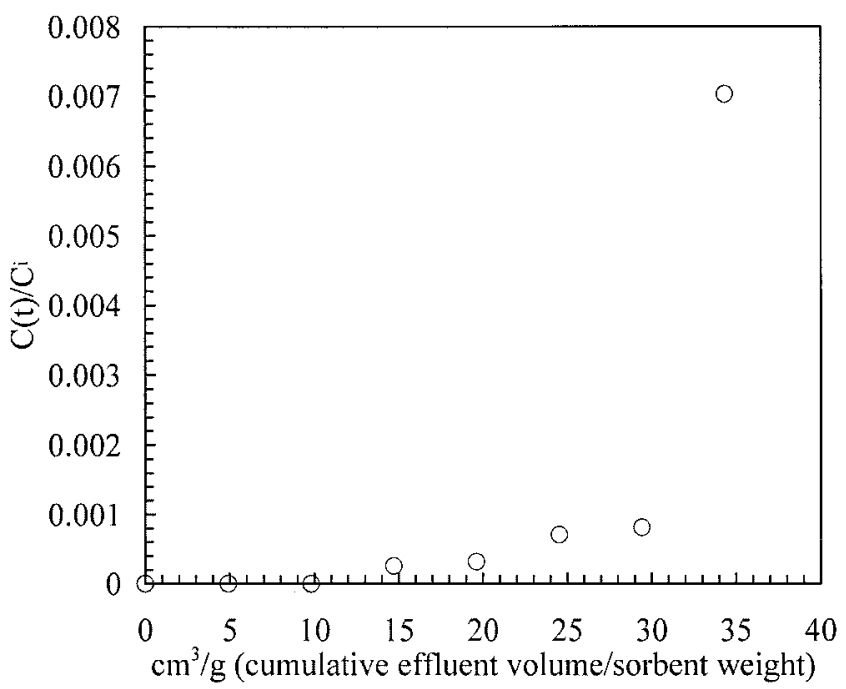

Figure 13. Breakthrough of total sulfur in a fixed-bed adsorber with $\mathrm{AC} / \mathrm{Cu}(\mathrm{I})-\mathrm{Y}$ adsorbents, for diesel feed at room-temperature.

$C_{i}$ is the total sulfur concentration in the feed $(=297.2$ ppmw sulfur). 


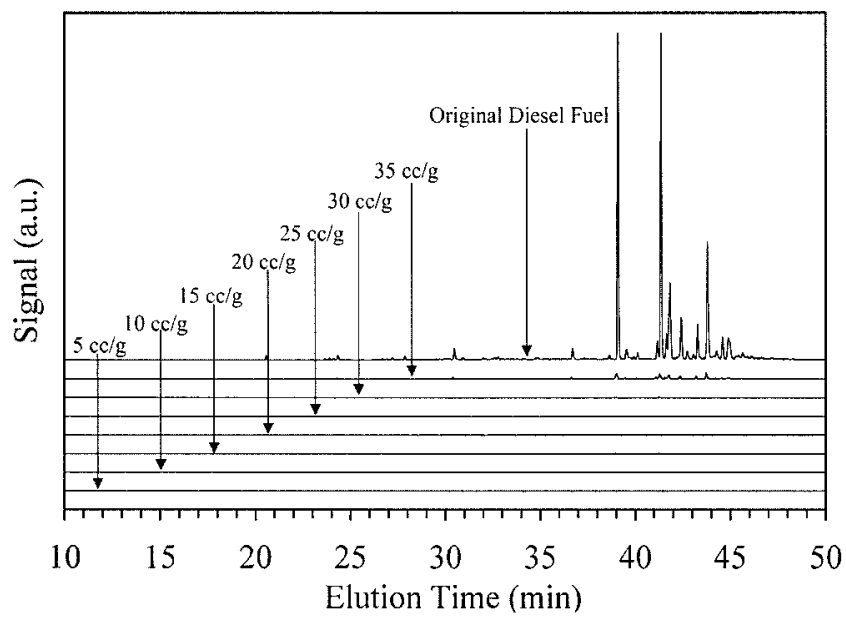

Figure 14. Progression of GC-FPD chromatograms of sulfur compounds in the effluent during diesel treatment with $\mathrm{AC} / \mathrm{Cu}(\mathrm{l})-\mathrm{Y}$.

Also shown is effluent volume normalized by the total weight of adsorbent.

ultra-low sulfur diesel is necessary, the adsorbent is capable of producing $20 \mathrm{~cm}^{3} / \mathrm{g}$ with a sulfur content of equal or less than 0.06 ppmw or 60 ppbw. Figure 14 shows the significant difference between GC-FPD data for untreated and treated diesel fuel after using the $\mathrm{AC} / \mathrm{Cu}(\mathrm{I})-\mathrm{Y}$ adsorbent.

\section{$\mathrm{Cu}(\mathrm{I})-\mathrm{Y}$ regeneration}

Hernández-Maldonado and Yang were able to completely regenerate $\mathrm{Cu}(\mathrm{I})-\mathrm{Y}$ zeolites after saturating them with thiophene molecules removed from liquid hydrocarbons (Yang et al., 2002; Hernández-Maldonado and Yang, 2003a). They found that using air at $350^{\circ} \mathrm{C}$ provides a suitable way to completely remove the sulfur containing molecules. After this treatment, the adsorbent needed to be autoreduced in an inert atmosphere to recover its activated form. A similar approach is used during the S Zorb desulfurization scheme developed by Phillips Petroleum. The S Zorb process removes sulfur species from fuels at high temperatures under a hydrogen atmosphere at high pressures. Afterward, the spent adsorbent is regenerated with nitrogen at temperatures of $37-538^{\circ} \mathrm{C}$ followed by contact with air at $427-650^{\circ} \mathrm{C}$ (Khare, 2001b). It should be mentioned that their adsorbent also needs to be reduced before reuse.

Although many other regeneration techniques (such as solvent elution) are believed to be appropriate for regeneration of spent $\pi$-complexation adsorbents after desulfurization of commercial fuels, more studies are required to determine the most suitable conditions. This will be reported later.

\section{Conclusion}

Results have demonstrated that copper (auto-reduced) type-Y zeolites are superior adsorbents for the removal of all sulfur compounds from commercial diesel fuels, based on dynamic fixed-bed adsorption experiments. When used with a guard bed, $\mathrm{Cu}(\mathrm{I})-\mathrm{Y}$ provides by far the best adsorption capacities both at breakthrough point and at saturation. For activated carbon acting as a guard bed, the process is capable of processing $30 \mathrm{~cm}^{3} / \mathrm{g}$ of diesel with an average sulfur content of
0.15 ppmw or 150 ppbw. In general, the adsorbents tested followed the following order for total sulfur adsorption capacity at breakthrough: $\mathrm{AC} / \mathrm{Cu}(\mathrm{I})-\mathrm{Y}>\mathrm{Cu}(\mathrm{I})-\mathrm{Y}>$ Selexsorb $\mathrm{CDX}>\mathrm{CuCl} / \gamma-\mathrm{Al}_{2} \mathrm{O}_{3}>$ activated carbon $>\mathrm{Cu}(\mathrm{I})-\mathrm{ZSM}-5$. For total sulfur adsorption capacity at saturation, the order was as follows: $\mathrm{AC} / \mathrm{Cu}(\mathrm{I})-\mathrm{Y}>\mathrm{Cu}(\mathrm{I})-\mathrm{Y}>$ Selexsorb $\mathrm{CDX}>$ activated carbon $>\mathrm{CuCl} / \gamma-\mathrm{Al}_{2} \mathrm{O}_{3}>\mathrm{Cu}(\mathrm{I})-\mathrm{ZSM}-5$. All adsorbents, with the exception of $\mathrm{Cu}(\mathrm{I})-\mathrm{ZSM}-5$, show some capacities for the refractory sulfur compounds. The $\mathrm{Cu}(\mathrm{I})-\mathrm{ZSM}-5$ zeolite, however, is promising for applications where selectivity toward small thiophene molecules is preferred.

\section{Acknowledgments}

Neutron activation analysis (NAA) was conducted in the Ford Nuclear Reactor of the Phoenix Memorial Laboratory at the University of Michigan. Dr. Leah Minc of the Michigan Phoenix Memorial Project conducted the analysis. Supports from NSF CTS-0138190 and DOE are acknowledged.

\section{Notation}

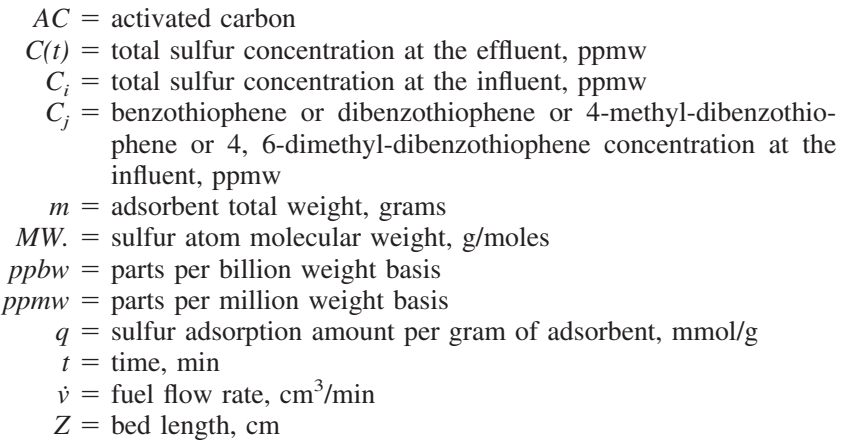

\section{Greek Letters}

$$
\rho=\text { fuel density, } \mathrm{g} / \mathrm{cm}^{3}
$$

\section{Literature Cited}

Bacaud, R., V. L. Cebolla, L. Membrado, M. Matt, S. Pessayre, and E. M. Gálvez, "Evolution of Sulfur Compounds and Hydrocarbons Classes in Diesel Fuels during Hydrodesulfurization. Combined Use of Thin-Layer Chromatography and GC-Selective Chemilumiscence Detection," Ind. Eng. Chem. Res., 41, 6005 (2002).

Baes, C. F., and R. E. Mesmer, The Hydrolysis of Cations, Wiley, New York (1976).

Breck, D. W., Zeolite Molecular Sieves, Wiley, New York (1973). [reprinted by Krieger, Malabar, Fla. (1984)]

Chawla, B., and F. Di Sanzo, "Determination of Sulfur Components in Light Petroleum Streams by High-Resolution Gas Chromatography with Chemiluminescence Detection," J. Chromatogr., 589, 271 (1992).

Cheng, L. S., and R. T. Yang, "Improved Horvath-Kawazoe Equations Including Spherical Pore Models for Calculating Micropore Size Distribution," Chem. Eng. Sci., 49, 2599 (1994).

Choma, J., W. Burakiewicz-Mortka, M. Jaroniec, and R. K. Gilpin, "Studies of the Structural Heterogeneity of Microporous Carbons Using Liquid/Solid Adsorption Isotherms," Langmuir, 9, 2555 (1993).

Collins, F. M., A. R. Lucy, and C. Sharp, "Oxidative Desulphurisation of Oils via Hydrogen Peroxide and Heteropolyanion Catalysis," J. Mol. Catal. A-Chem., 117, 397 (1997).

Fowkes, A. J., R. M. Ibberson, and M. J. Rosseinsky, "Structural Characterization of the Redox Behavior in Copper-Exchanged Sodium Zeolite Y by High Resolution Powder Neutron Diffraction," Chem. Mater., 14, 590 (2002).

Gates, B. C., and H. Topsøe, "Reactivities in Deep Catalytic Hydrodesulfurization Challenges, Opportunities and the Importance of 4-Methyldibenzothiophene and 4, 6-Dimethyldibenzothiophene," Polyhedron, 16, 3213 (1997). 
Golden, T. C., W. C. Kratz, and F. C. Wilhelm, "Highly Dispersed Cuprous Compositions,” U. S. Patent 5, 126, 310 (1992a).

Golden, T. C., W. C. Kratz, F. C. Wilhelm, R. Pierantozzi, and A. Rokicki, "Highly Dispersed Cuprous Compositions," U. S. Patent 5, 175, 137 (1992b).

Golden, T. C., D. E. Guro, W. C. Kratz, J. M. Occhialini, and T. E. Sabram, "APCI's CO VSA: Design, Scale-Up and Plant Performance," in Fundamentals of Adsorption, by F. Meunier, Ed., Elsevier, Amsterdam (1998).

Hernández-Maldonado, A. J., and R. T. Yang, "Desulfurization of Liquid Fuels by Adsorption via $\pi$-Complexation with $\mathrm{Cu}(\mathrm{I})-\mathrm{Y}$ and $\mathrm{Ag}-\mathrm{Y} \mathrm{Zeo}-$ lites," Ind. Eng. Chem. Res., 42, 123 (2003a).

Hernández-Maldonado, A. J., and R. T. Yang, "Desulfurization of Commercial Liquid Fuels by Selective Adsorption via $\pi$-Complexation with Cu(I)-Y Zeolite," Ind. Eng. Chem. Res., 42, 3103 (2003b).

Horvath, G., and K. Kawazoe, "Method for Calculation of Effective Pore Size Distribution in Molecular Sieve Carbon," J. Chem. Eng. Jpn., 16, 470 (1983).

Hu, J. L., Y. Wang, D. Vander Wiel, C. Chin, D. Palo, R. Rozmiarek, R. Dagle, J. Cao, J. Holladay, and E. Baker, "Fuel Processing for Portable Power Applications," Chem. Eng. J., 93, 55 (2003).

Huang, H. Y., J. Padin, and R. T. Yang, "Anion and Cation Effects on Olefin Adsorption on Silver and Copper Halides: Ab Initio Effective Core Potential Study of $\pi$-Complexation," J. Phys. Chem. B, 103, 3206 (1999a).

Huang, H. Y., J. Padin, and R. T. Yang, "Comparison of $\pi$-Complexations of Ethylene and Carbon Monoxide and $\mathrm{Cu}^{+}$and $\mathrm{Ag}^{+}$," Ind. Chem. Res., 38, 2720 (1999b).

Irvine, R. L., "Process for Desulfurizing Gasoline and Hydrocarbon Feedstocks," U.S. Patent 5,730, 860 (1998).

Iwamoto, M., H. Yahiro, K. Tanda, N. Mizuno, Y. Mine, and S. Kagawa, "Removal of Nitrogen Monoxide through a Novel Catalytic Process: 1. Decomposition on Excessively Copper Ion-Exchanged ZSM-5 Zeolites," J. Phys. Chem., 95, 3727 (1991).

Jayaraman, A., R. T. Yang, C. L. Munson, and D. Chinn, "Deactivation of $\pi$-Complexation Adsorbents by Hydrogen and Rejuvenation by Oxidation," Ind. Eng. Chem. Res., 40, 4370 (2001).

Khare, G. P., "Process for the Production of a Sulfur Sorbent," U.S. Patent 6, 184,176 (2001a).

Khare, G. P., "Desulfurization Process and Novel Bimetallic Sorbent Systems for Same," U.S. Patent 6, 274, 533 (2001b).

King, C. J., "Separation Processes Based on Reversible Chemical Complexation," In Handbook of Separation Process Technology, Rousseau, R.W., ed., Wiley, New York (1987).

King, D. L., C. Faz, and T. Flynn, "Desulfurization of Gasoline Feedstocks for Application in Fuel Reforming," SAE Paper 2000-01-0002, Society of Automotive Engineers, Detroit, MI (2000).

Kiselev, D. V., Y. A. Eltekov, and V. N. Semenova, Kinetic. Katal., 3, 421 (1962).

Knudsen, K. G., B. H. Cooper, and H. Topsøe, "Catalyst and Process Technologies for Ultra Low Sulfur-Diesel,” Appl. Catal. A-Gen., 189, 205 (1999).

Krause, C., "An Emissions Mission: Solving the Sulfur Problem," Oak Ridge National Lab Review, 33, 3 (2000).

Kumar, R., W. C. Kratz, D. E. Guro, and T. C. Golden, "A New Process for the Production of High Purity Carbon Monoxide and Hydrogen," Separation Technology: Proc. of the Third Int. Symp., E. F. Vansant, ed., Elsevier, Amsterdam, Univ. of Antwerp, Belgium (1994).

Lamberti, C., G. Spoto, D. Scarano, C. Pazé, M. Salvalaggio, S. Bordiga, A. Zecchina, G. Turnes Palomino, and F. D' Acapito, " $\mathrm{Cu}^{\mathrm{I}}-\mathrm{Y}$ and $\mathrm{Cu}^{\mathrm{II}}-\mathrm{Y}$ Zeolites: a XANES, EXAFS and visible-NIR Study," Chem. Phys. Lett., 269, 500 (1997).

Larsen, S. C., A. Aylor, A. T. Bell, and J. A. Reimer, "Electron Paramagnetic Resonance Studies of Copper Ion-Exchanged ZSM-5," J. Phys. Chem., 98, 11533 (1994).

Ma, X., K. Sakanishi, and I. Mochida, "Hydrodesulfurization Reactivities of Various Sulfur Compounds in Diesel Fuel," Ind. Eng. Chem. Res., 33, 218 (1994).

Ma, X., K. Sakanishi, T. Isoda, and I. Mochida, "Determination of Sulfur Compounds in Non-Polar Fraction of Vacuum Gas Oil," Fuel., 76, 329 (1997).

Ma, X., M. Sprague, L. Sun, and C. Song, "Deep Desulfurization of Liquid
Hydrocarbons by Selective Adsorption for Fuel Cell Applications," Am. Chem. Soc. Div. Pet. Chem. Prepr., 47, 48 (2002a).

Ma, X., L. Sun, and C. Song, “A New Approach to Deep Desulfurization of Gasoline, Diesel Fuel and Jet Fuel by Selective Adsorption for Ultra-Clean Fuels and for Fuel Cell Applications," Catal. Today., 77, 107 (2002b).

Padin, J., and R. T. Yang, "Tailoring New Adsorbents Based on $\pi$-Complexation: Cation and Substrate Effects on Selective Acetylene Adsorption," Ind. Eng. Chem. Res., 36, 4224 (1997).

Padin, J., R. T. Yang, and C. L. Munson, "New Sorbents for Olefin-Paraffin Separations and Olefin Purification for $\mathrm{C}_{4}$ Hydrocarbons," Ind. Eng. Chem. Res., 38, 3614 (1999).

Padin, J., and R. T. Yang, "New Sorbents for Olefin-Paraffin Separations by Adsorption via $\pi$-Complexation: Synthesis and Effects of Substrates," Chem. Eng. Sci., 55, 2607 (2000).

Parkinson, G., "Diesel Desulfurization Puts Refiners in a Quandary," Chem. Eng., 108, 37 (2001).

Parrillo, D. J., D. Dolenec, R. J. Gorte, and R. W. McCabe, "Adsorption Studies on CuZSM-5: Characterization of the Unique Properties of Ion-Exchanged Cu," J. Catal., 142, 708 (1993).

Rege, S. U., J. Padin, and R. T. Yang, "Olefin-Paraffin Separations by Adsorption: $\pi$-Complexation vs Kinetic Separation,” AIChE J., 44, 799 (1998).

Saito, A., and H. C. Foley, "Curvature and Parametric Sensitivity in Models for Adsorption in Micropore," AIChE J., 37, 429 (1991).

Sarkany, J., J. L. Ditri, and W. M. H. Sachtler, "Redox Chemistry in Excessively Ion-Exchanged Cu/Na-ZSM-5," Catal. Lett., 16, 241 (1992).

Seader, J. D., and E. J. Henley, Separation Process Principles, Wiley, New York (1998).

Smith, J.V., "Faujasite-Type Structures. Aluminosilicate Framework. Positions of Cations and Molecules. Nomenclature," Adv. Chem. Ser., 101, 171 (1971).

Takahashi, A., F. H. Yang, and R. T. Yang, "Aromatics/Aliphatics Separation by Adsorption: New Sorbents for Selective Aromatics Adsorption by $\pi$-Complexation," Ind. Eng. Chem. Res., 39, 3856 (2000).

Takahashi, A., R. T. Yang, C. L. Munson, and D. Chinn, "Cu(I)-Y-Zeolite as a Superior Adsorbent for Diene/Olefin Separation," Langmuir, 17, 8405 (2001).

Takahashi, A., F. H. Yang, and R. T. Yang, "New Sorbents for Desulfurization by $\pi$-Complexation: Thiophene/Benzene Adsorption," Ind. Eng. Chem. Res., 41, 2487 (2002).

Turnes Palomino, G., S. Bordiga, A. Zecchina, G. L. Marra, and C. Lamberti, "XRD, XAS, and IR Characterization of Copper-Exchanged Y Zeolite," J. Phys. Chem. B, 104, 8641 (2000).

Valyon, J., and W. K. Hall, "Effects of Reduction and Reoxidation on the Infrared-Spectra from Cu-Y and Cu-ZSM-5 Zeolites," J. Phys. Chem., 97, 7054 (1993).

Wardencki, W., and R. Staszewski, "Dynamic Adsorption of Thiophenes, Thiols and Sulphides from $n$-heptane Solutions on Molecular Sieve 13X," J. Chromatogr., 91, 715 (1974).

Weitkamp, J., M. Schwark, and S. Ernst, "Removal of Thiophene Impurities from Benzene by Selective Adsorption in Zeolite ZSM-5," J. Chem. Soc., Chem. Comm., 16,1133 (1991).

Yang, R. T., Gas Separation by Adsorption Processes, Imperial College Press, River Edge, NJ (1997).

Yang, R. T., Adsorbents: Fundamentals and Applications, Wiley, New York (2003).

Yang, R. T., A. J. Hernández-Maldonado, and F. H. Yang, "Desulfurization of Transportation Fuels with Zeolites Under Ambient Conditions," Science, 301, 79 (2003).

Yang, R. T., and E. S. Kikkinides, "New Sorbents for Olefin-Paraffin Separations by Adsorption via $\pi$-Complexation," AIChE J., 41, 509 (1995).

Yang, R. T., A. Takahashi, and F. H. Yang, "New Sorbents for Desulfurization of Liquid Fuels by $\pi$-Complexation," Ind. Eng. Chem. Res., 40, 6236 (2001).

Yang, R. T., A. Takahashi, F. H. Yang, and A. Hernández-Maldonado, "Selective Sorbents for Desulfurization of Liquid Fuels," U.S. and foreign Patent applications filed (2002).

Revision received April 11, 2003, received Aug 11, 2003 